\title{
Survival of seaward-migrating PIT and acoustic-tagged juvenile Chinook salmon in the Snake and Columbia Rivers: an evaluation of length-specific tagging effects
}

\author{
Richard S Brown ${ }^{1 *}$, Eric W Oldenburg ${ }^{1}$, Adam G Seaburg ${ }^{2}$, Katrina V Cook', John R Skalski ${ }^{2}$, M Brad Eppard ${ }^{3}$ \\ and Katherine A Deters ${ }^{1}$
}

\begin{abstract}
Background: Acoustic telemetry is a widely used tool for evaluating the behavior and survival of juvenile salmonids in the Columbia River basin. Thus, it is important to understand how the surgical tagging process and the presence of a transmitter affect survival. This study evaluated the effect of fish length on the survival of yearling and subyearling Chinook salmon during their seaward migrations through the Snake and Columbia Rivers during 2006, 2007, and 2008. Fish were collected at Lower Granite Dam on the Snake River (695 river km from the mouth of the Columbia) and implanted with either only a passive integrated transponder (PIT) tag (PIT fish) or both a PIT tag and an acoustic transmitter (AT fish).
\end{abstract}

Results: Across the 3 years, a total of 157,000 yearling and subyearling fish were tagged and designated as PIT fish and 18,500 as AT fish. Survival was estimated from release at Lower Granite Dam to multiple downstream dams using the Cormack-Jolly-Seber single release model, and analysis of variance was used to test for differences among length classes for both tag types. No length-specific tag effect was detected between PIT and AT fish (that is, length affected the survival of PIT fish and AT fish in a similar manner). Fish length was positively correlated with the survival of both PIT and AT fish. Survival was markedly low among the smallest length class (that is, $80 \mathrm{~mm}$ to $89 \mathrm{~mm}$ ) of both PIT and AT subyearling Chinook salmon and the survival of PIT fish was generally greater than that of AT fish.

Conclusions: The lack of a length-specific tag effect suggests that under the conditions used in this study, differences in survival between PIT and AT fish may be due to the process of surgically implanting the transmitter rather than the presence of the transmitter.

Keywords: Tag effect, Telemetry, Tag burden, Juvenile Chinook salmon, Dams, Columbia river

\section{Background}

Acoustic and radio telemetry are used throughout the world to examine fish behavior and survival [1,2]. Field studies typically assume that the presence of a transmitter and the process of implanting the transmitter do not affect the survival, behavior, or performance of fish (that is, tagged individuals are representative of the population

\footnotetext{
* Correspondence: Rich.brown@pnnl.gov

'Pacific Northwest National Laboratory, Ecology Group, Post Office Box 999, Richland, WA 99352, USA

Full list of author information is available at the end of the article
}

of interest [3]). Deviations from this assumption are hereafter referred to as tag effects. Research has been conducted to evaluate tag effects among many species, transmitter types and sizes, and geographic areas. Specifically, laboratory research has evaluated the survival, growth, tag expulsion, swimming performance, stress levels, and predation of tagged versus untagged fish [4-11]. In these studies, untagged or sham-tagged fish (that is, fish handled in a manner identical to treatment fish, including incisions, but not implanted with a transmitter) typically serve as a comparison to tagged fish.

\section{Biomed Central}

(c) 2013 Brown et al.; licensee BioMed Central Ltd. This is an Open Access article distributed under the terms of the Creative Commons Attribution License (http://creativecommons.org/licenses/by/2.0), which permits unrestricted use, distribution, and reproduction in any medium, provided the original work is properly cited. 
However, field studies evaluating tag effects may be more informative than laboratory studies because they can combine all of the metrics examined in the laboratory (for example, survival, growth, swimming performance, and predation) into a more comprehensive and relevant evaluation.

Few field studies have evaluated tag effects. It is not feasible to compare tagged fish to control or shamtagged fish because the survival, behavior, and performance of untagged fish cannot be monitored effectively. Thus, field research studies evaluating tag effects often use fish tagged with passive integrated transponder (PIT) tags to serve as controls (for example, [12]). Provided a fish is large enough for a PIT tag, the implantation (that is, injection) and presence of a 0.1-g PIT tag is assumed to produce minimal tag effects relative to effects that may be expected from larger telemetry transmitters or from transmitters requiring surgical implantation [12]. Although the growth and survival of PIT-tagged fish may not be perfectly representative of their untagged conspecifics [13], it is the best-case scenario given the inability to monitor untagged fish in the wild.

Fish implanted with PIT tags have commonly been used as controls in the US Pacific Northwest to examine the influence of hydroelectric dams on the survival of juvenile salmonids during their seaward migrations. For example, Hockersmith et al. [12] examined the difference in survival between PIT-tagged and radio-tagged (monitored with a PIT tag embedded in the dummy tag) migrant yearling Chinook salmon, Oncorhynchus tshawytscha, within the Snake and Columbia Rivers and found no differences in survival to downstream detection points (Table 1, Figure 1). In a similar study, when survival of PIT-tagged yearling Chinook salmon was compared to their acoustic-tagged conspecifics (also bearing a PIT tag), differences between tagging groups to these same locations were as high as $11 \%$ but were not statistically significant [14] (Table 1). Two years of additional research on yearling Chinook salmon in this system using the same methodology found differences of $7 \%$ or less up to $225 \mathrm{~km}$ away from release $[15,16]$ (Table 1). However, the differences in survival between acoustic- and PIT-tagged salmon noted by Wargo-Rub et al. [15] became greater as fish migrated farther downstream. Wargo-Rub et al. [15] also examined differences in survival between smaller PIT-tagged and acoustictagged subyearling Chinook salmon and found large differences in survival where acoustic-tagged fish had considerably reduced survival to two downstream detection points (that is differences of $16 \%$ and $33 \%$; Table 1 ). A similar study comparing survival between seawardmigrating PIT and acoustic-tagged yearling Chinook salmon in the mid-Columbia River from the tailrace of Rocky Reach Dam to the tailrace of Rock Island Dam in the Columbia River failed to see differences in survival $[17,18]$. However, the acoustic-tagged fish studied were larger than the PIT-tagged fish. In this same study area, Skalski et al. [19] found that among hatchery-reared steelhead, survival was significantly lower in those implanted with acoustic transmitters than PIT-tagged fish. Collectively these field results suggest that survival

Table 1 Differences in survival rates between PIT-tagged and surgically implanted yearling and subyearling Chinook salmon

\begin{tabular}{|c|c|c|c|c|c|c|c|c|c|c|c|c|c|}
\hline \multirow[b]{2}{*}{ Detection location } & \multirow{2}{*}{$\begin{array}{c}\text { km } \\
\text { downstream }\end{array}$} & \multicolumn{3}{|c|}{ Hockersmith et al. [12] } & \multicolumn{3}{|c|}{ Hockersmith et al. [14] } & \multicolumn{3}{|c|}{ Wargo-Rub et al. [15] } & \multicolumn{3}{|c|}{ Wargo-Rub et al. [16] } \\
\hline & & RT & PIT & $P$ value & AT & PIT & $P$ value & AT & PIT & $P$ value & $\overline{\text { AT }}$ & PIT & $P$ value \\
\hline \multicolumn{14}{|l|}{ Yearling } \\
\hline Little Goose Dam & 60 & 0.62 & 0.598 & 0.307 & 1.00 & 0.89 & 0.004 & 0.93 & 0.93 & 0.893 & 0.92 & 0.95 & 0.107 \\
\hline Lower Monumental Dam & 106 & 0.554 & 0.507 & 0.591 & 0.88 & 0.83 & 0.222 & 0.92 & 0.88 & 0.08 & 0.88 & 0.93 & 0.096 \\
\hline Ice Harbor Dam & 157 & NA & NA & NA & NA & NA & NA & 0.81 & 0.84 & 0.285 & 0.80 & 0.83 & 0.336 \\
\hline McNary Dam & 225 & 0.328 & 0.343 & 0.427 & 0.70 & 0.79 & 0.102 & 0.72 & 0.78 & 0.054 & 0.68 & 0.75 & 0.095 \\
\hline John Day Dam & 348 & NA & NA & NA & 0.61 & 0.65 & 0.538 & 0.62 & 0.72 & 0.01 & 0.60 & $0.83^{\mathrm{a}}$ & 0.001 \\
\hline Bonneville Dam & 460 & NA & NA & NA & 0.48 & 0.54 & 0.547 & 0.50 & 0.63 & 0.001 & 0.52 & $0.75^{\mathrm{a}}$ & 0.021 \\
\hline \multirow[t]{2}{*}{ Subyearling } & & \multicolumn{3}{|c|}{ Wargo-Rub et al. [15] } & & & & & & & & & \\
\hline & & AT & PIT & $\mathbf{P}$ & & & & & & & & & \\
\hline Little Goose Dam & 60 & 0.65 & 0.81 & 0.003 & & & & & & & & & \\
\hline McNary Dam & 225 & 0.23 & 0.56 & $<0.001$ & & & & & & & & & \\
\hline
\end{tabular}

Fish were either surgically implanted with a sham radio transmitter (RT) containing an embedded PIT tag or an acoustic tag and a PIT tag (AT). All fish in these four studies were tagged at Lower Granite Dam ( $695 \mathrm{~km}$ upstream from the Pacific Ocean) and released in the Snake River just downstream of the dam. Fish were detected by PIT detectors at several downstream dams (distance downstream from release shown) on their seaward migration. The datasets from Hockersmith et al. [14] and Wargo-Rub et al. [15,16] were used to assess length-specific tag effects.

a In 2008 at these two locations, the PIT data collected did not conform to statistical model assumptions and these estimates are considered problematic or inaccurate [20]. AT acoustic transmitter, NA not applicable, RT radio transmitter, PIT passive integrated transponder. 


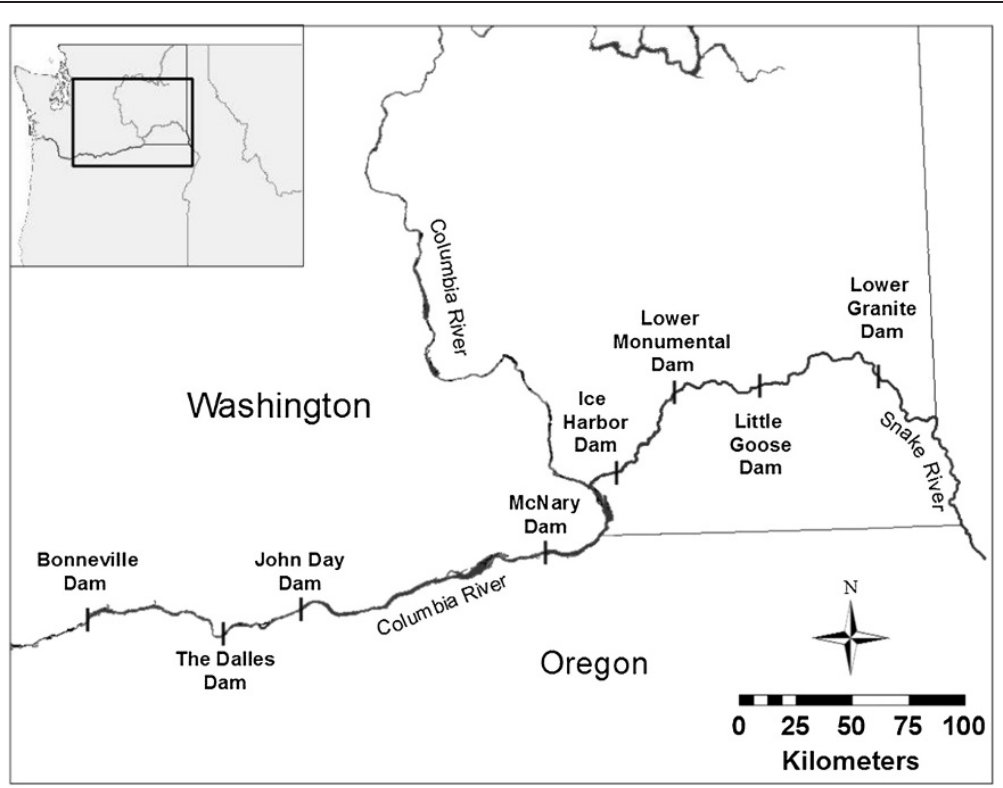

Figure 1 Study map. A map of dams on the Snake and Columbia Rivers in the Pacific Northwest of the United States. Acoustic tagging of yearling and subyearling Chinook salmon occurred at Lower Granite Dam and fish were detected at points on or near subsequent downstream dams.

may be lower for acoustic-tagged fish compared to PITtagged fish but that results could be influenced by fish size (that is, no differences were detected where acoustic-tagged fish were larger than PIT-tagged fish).

Among both field and lab studies, individuals implanted with tags generally represent a range of sizes similar to the range of the population from which they were sampled and may represent an age-class of fish such as yearling or subyearling Chinook salmon (for example, $[6,8,21])$. Analyses thus estimate tag effects for the entire group of fish but do not provide insight as to whether some of the smaller fish within a group experience greater tag effects than larger members of the group.

The point at which fish are too small to tag (that is, a size limit exists) or at which negative effects from tag burden (ratio of transmitter weight to fish weight) begin to manifest is an issue that has been of concern for many years. Laboratory studies have attempted to set recommendations and further studies are challenging these recommendations by examining tag effects on salmonids along a range of sizes. Zale et al. [22] examined the minimum size at which fish could be tagged without influencing the growth and swimming performance of small cutthroat trout O. clarkii (tag burden range: 0.5\% to $5.3 \%$ ) implanted with dummy radio transmitters. There was no relationship between tag burden and swimming performance, but there were subtle decreases in growth as tag burden increased. In another laboratory study, Brown et al. [11] examined growth and survival of juvenile Chinook salmon $(80 \mathrm{~mm}$ to $110 \mathrm{~mm}$ ) implanted with an acoustic transmitter and PIT tag (tag burden range: $4.5 \%$ to $15.7 \%$ ). Survival and growth of implanted fish were negatively affected at tag burdens of $6.7 \%$ and $8.2 \%$, respectively, over a 30 -day period.

Although research of this type has been conducted in the laboratory, there has been no field-based research examining tag effects along a range of fish sizes. Thus, the goals of this research were to determine if a lengthspecific tag effect was present among seaward-migrating juvenile Chinook salmon implanted with an acoustic transmitter and a PIT tag, and to identify the minimum length at which Chinook salmon could be implanted with an acoustic transmitter and PIT tag without causing significant tag effects. While the 3 years of research reported by Hockersmith et al. [14] and Wargo-Rub et al. $[15,16]$ examined differences in detection probability, survival, and travel time between PIT- and acoustictagged Chinook salmon, length-specific tag effects were not examined. This effort further explores these same datasets to determine if length-specific tag effects exist and if a size limit based on field research is appropriate.

\section{Results}

\section{Yearling Chinook salmon}

During each year, one group was tagged with PIT tags (hereafter referred to as PIT fish) and another group was tagged with both PIT tags and acoustic transmitters (hereafter referred to as AT fish). Yearling Chinook salmon tagged in this study ranged from $100 \mathrm{~mm}$ to 159 $\mathrm{mm}$ (Table 2) and the median tag burden of AT fish within each $10-\mathrm{mm}$ length-class varied from $1.6 \%$ to 
Table 2 Number, size and tag burdens of subyearling and yearling Chinook salmon tagged with either a PIT tag or with a PIT tag and an acoustic tag (AT Fish) and released at Lower Granite Dam across three years

\begin{tabular}{lccccc}
\hline & & \multicolumn{2}{c}{ Sample size } & & \\
\cline { 3 - 4 } Stock & Year & PIT & AT & Fork length range (mm) & Median (range) AT tag burden (\%) \\
\hline Yearling & 2006 & 19,111 & 898 & $120-149$ & $3.2(2.2-5.0)$ \\
& 2007 & 49,167 & 3,755 & $110-159$ & $3.6(2.0-7.4)$ \\
& 2008 & 53,592 & 4,087 & $100-159$ & $2.3(1.2-7.4)$ \\
Subyearling $^{a}$ & 2007 & 35,793 & 9,760 & $80-129$ & $6.3(2.5-15.1)$ \\
\hline
\end{tabular}

${ }^{a}$ Survival estimates from release to LMN were not produced for subyearling Chinook salmon ranging in fork length from $80 \mathrm{~mm}$ to $89 \mathrm{~mm}$ or $120 \mathrm{~mm}$ to $129 \mathrm{~mm}$ due to low PIT detection probabilities for these length-classes, causing unreliable estimates. Sample sizes to LMN were thus 32,904 (PIT) and 8,641 (AT).

AT acoustic transmitter, PIT passive integrated transponder.

Fork length indicates the range of fish sizes included in the analysis for a given year and stock. Tag burdens were calculated as weight of fish/weight of tag (PIT + AT tag weights).

5.7\% (Figure 2). Mean detection probability (all years and detection locations pooled) of PIT fish was 0.18 and decreased with increasing fish length, varying from 0.13 to 0.22 among length-classes (Figure 3). Mean detection probability of AT fish was 0.98 and varied little among length-classes (that is, 0.97 to 0.99; Figure 3).

Fork length explained much of the variability in survival among yearling Chinook salmon. The coefficient of determination increased from 2006 through 2008 and was generally greater for AT fish compared to that for PIT fish (Figure 4). Length was positively correlated with survival for 18 of the 20 cohort-river reach combinations (10 PIT and 10 AT combinations) of yearling Chinook salmon. Length was negatively correlated with survival for only the 2006 PIT fish in the reaches ending at Lower Monumental Dam and Ice Harbor Dam. Length significantly affected survival in seven of the ten cohort-reach combinations examined (tag types pooled;
Figure 4): larger fish had a higher survival probability. All three non-significant results were from the 2006 cohort where the lowest sample sizes and fewest length classes were examined.

Tag type significantly affected survival in seven of the ten cohort-reach combinations examined: PIT fish had a higher survival probability (Figure 4). Two of the nonsignificant results came again from the 2006 cohort. In general, survival of yearling Chinook salmon decreased with increasing distance from release (Figure 4). The effect size between PIT and AT yearling Chinook salmon survival also generally increased with increasing distance from release (Figure 4). These survival results are based on PIT and AT detections that are not from the exact same locations. Further information on tag-type survival differences can be found in Hockersmith et al. [14] and Wargo-Rub et al. $[15,16]$. These reports focus on tagtype tagging effects rather than length-specific tag effects

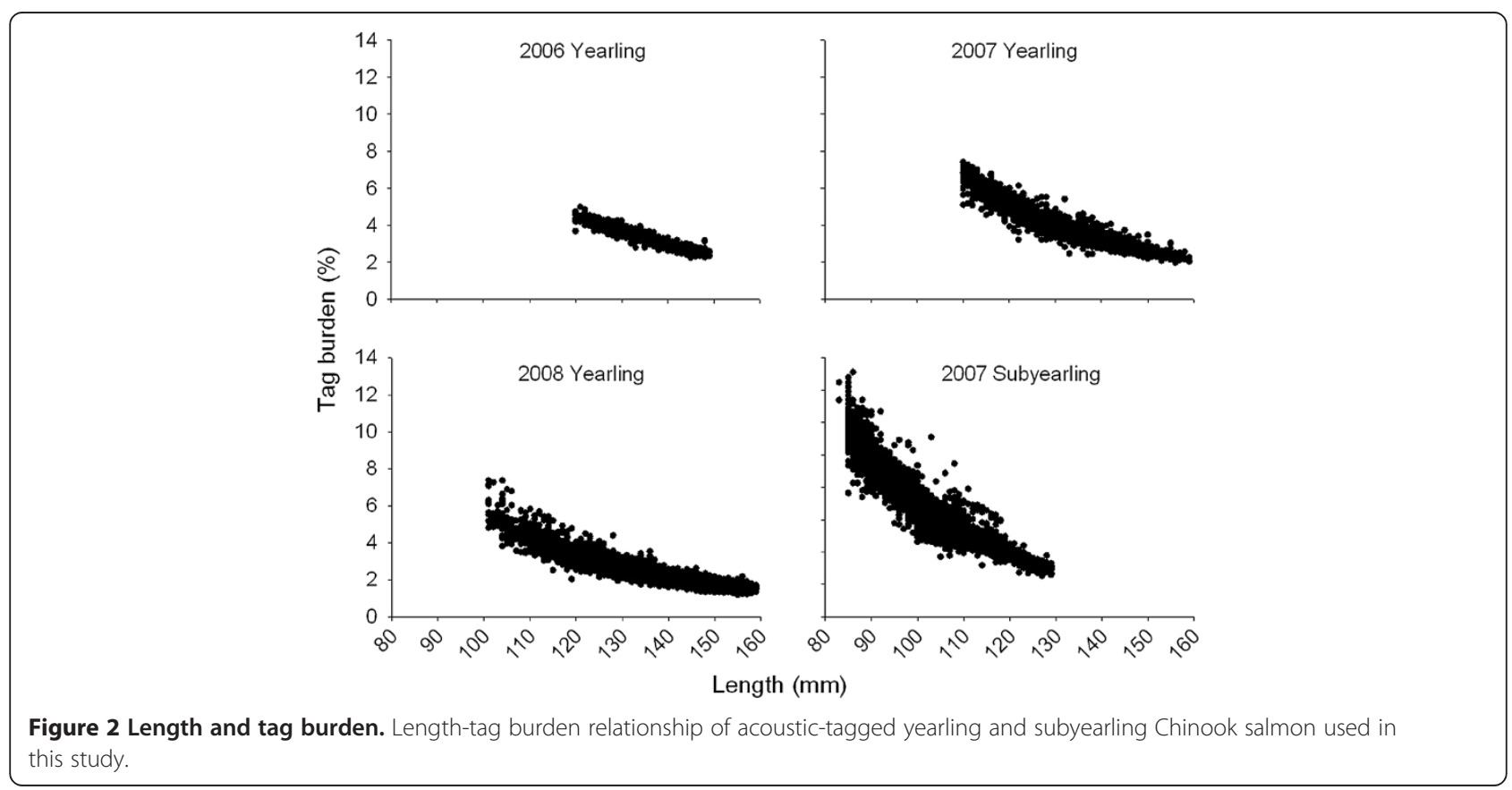




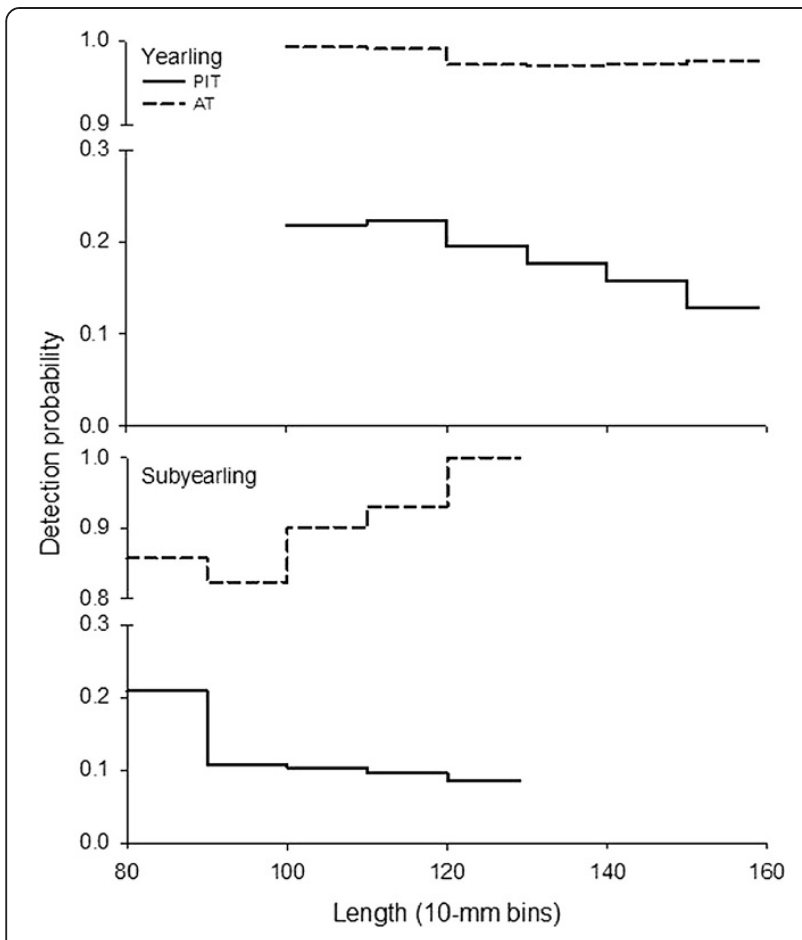

Figure 3 Detection probabilities with length for each tag type. Length-specific detection probabilities of yearling Chinook salmon (upper panel; all years and detection locations pooled) and subyearling Chinook salmon in 2007 (lower panel; all detection locations pooled). AT: acoustic transmitter; PIT: passive integrated transponder.

and present survival estimates using PIT detections only. Results from these studies are also summarized in Table 1.

Length-specific tag effects are determined by the interaction term of this analysis. The length-tag type interaction was non-significant $(\alpha=0.05)$ for all cohortreach combinations examined (Figure 4). Thus, length did not affect the survival of PIT fish differently from AT fish and no length-specific tag effect existed between tag types.

\section{Subyearling Chinook salmon}

Subyearling Chinook salmon tagged in this study varied from $80 \mathrm{~mm}$ to $129 \mathrm{~mm}$ (Table 2) and the median tag burden of AT fish ranged from $4.7 \%$ to $10.6 \%$ within each 10-mm length-class (Figure 2). The mean detection probability (detection locations pooled) of PIT fish was 0.12 and generally decreased with increasing fish size, varying from 0.08 to 0.21 among length-classes (Figure 3). The mean detection probability of AT fish was 0.90 and generally increased with increasing fish size, varying from 0.82 to 1.00 among length-classes (Figure 3). However, detection probabilities observed at the McNary Dam acoustic receiver array were aberrantly length-specific among AT fish and were between 0.99 and 1.00 among all other detection locations and lengthclasses (Figure 3).

Length explained much of the variability in survival among subyearling Chinook salmon. The coefficient of determination was greater for AT fish compared to that of PIT fish in all three reaches (Figure 5). Length was positively correlated with survival for all six subyearling Chinook salmon cohort-reach combinations examined. Length significantly affected survival in two of the three reaches examined (tag types pooled; Figure 5).

Tag type significantly affected survival through two of the three reaches examined (Figure 5). In general, the survival of subyearling Chinook salmon decreased with increasing distance from release (Figure 5). The effect size between PIT and AT subyearling Chinook salmon survival increased with increasing distance from release (Figure 5). For both independent variables (tag type and length), there were significant effects on survival for the reaches from Lower Granite Dam to Ice Harbor and McNary dams but not for the shortest reach (Lower Granite Dam to Lower Monumental Dam). The survival of yearling Chinook salmon in 2007 was generally greater than that of subyearling Chinook salmon for both tag types in length-classes in which the size distributions overlapped (that is, $110 \mathrm{~mm}$ to $129 \mathrm{~mm}$; Figures 3 and 4).

The length-tag type interaction was non-significant for all subyearling Chinook salmon reaches examined (Figure 5). Thus, as with yearling fish, length did not affect the survival of PIT fish differently from AT fish (that is, no length-specific tag effect existed between tag types).

\section{Discussion}

This expansive 3-year study found no evidence of a length-specific tag effect among yearling Chinook salmon ranging from $100 \mathrm{~mm}$ to $159 \mathrm{~mm}$ (the median tag burden of AT fish within each 10-mm length-class varied from $1.6 \%$ to $5.7 \%$ ), as indicated by a non-significant length-tag type interaction effect on survival probability. Thus, it appears that under the conditions used in this study (for example, fish length, tag burden, and transmitter size), no minimum length limit is necessary for yearling Chinook salmon. Similar results were found for subyearling Chinook salmon varying from $80 \mathrm{~mm}$ to 129 $\mathrm{mm}$ (the median tag burden of AT fish within each 10 -mm length-class varied from $4.7 \%$ to $10.6 \%$ ). However, the survival of the smallest length-class $(80 \mathrm{~mm}$ to $89 \mathrm{~mm}$; median tag burden of AT fish $=10.6 \%$ ) of both PIT and AT subyearling Chinook salmon was markedly lower (for example, survival probability to McNary Dam was 3\% among PIT fish and 4\% among AT fish) than that of the larger length-classes (for example, survival probability to McNary Dam among all but the smallest 
length-class varied from $36 \%$ to $49 \%$ among PIT fish and $11 \%$ to $22 \%$ among AT fish). Interestingly, Connor et al. [23] also noted a marked decrease in survival among small subyearling Chinook salmon and recommended that hatchery fish be reared to lengths greater than 90 $\mathrm{mm}$ prior to release.
Generally, the survival of subyearling Chinook salmon is reduced compared to yearlings likely due to slow travel rates, higher water temperatures and lower water discharge $[15,24]$. The cause of the precipitous decrease in survival observed for the smallest length-class of subyearling Chinook salmon remains unknown. However, it may be
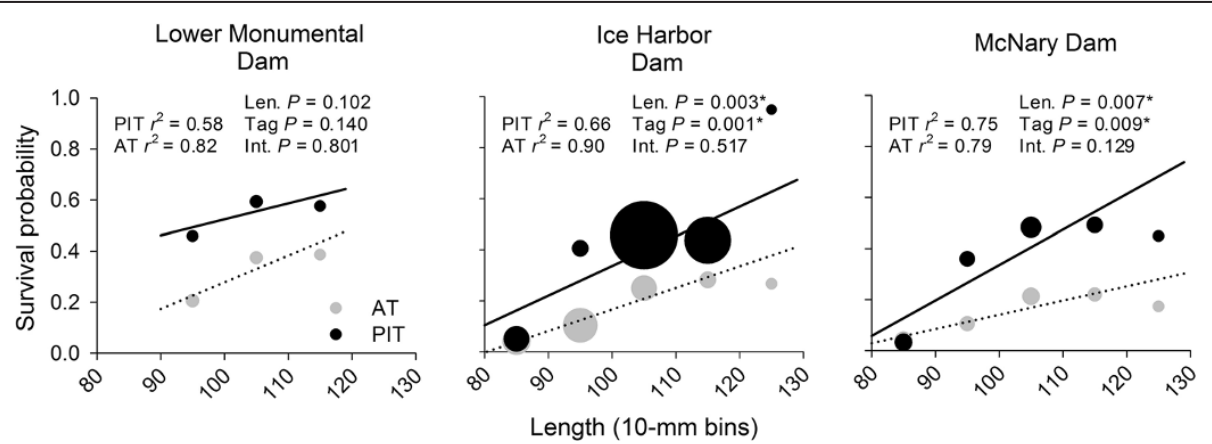

Figure 5 Survival probability with length of subyearling Chinook for each tag type and reach. Survival of acoustic-tagged (AT) and PITtagged (PIT) subyearling Chinook salmon from release at Lower Granite Dam to Lower Monumental Dam, Ice Harbor Dam, and McNary Dam in 2007. Dot size represents the weight of each length-class point estimate. Results are plotted at the mean value of the length range (that is, bin). Results are based on weighted linear regression and $P$ values are from weighted analysis of variance $(a=0.05)$. AT: acoustic transmitter; Int:: interaction; Len.: length; PIT: passive integrated transponder; Tag: tag type. 
more likely related to natural mortality rates than tagging effects as no length-specific tag effect was observed during this study. Connor et al. [24] also observed the lowest survival among small subyearlings and suggested this was because they were more susceptible to predation and were more prone to linger, increasing exposure to low water discharge and warm water temperatures for long durations. Variation in migration timing may also explain the observed low survival rates among small subyearling Chinook salmon. A life-history variation (that is, reservoir-type) exists in which some fall Chinook salmon from the Snake River Basin migrate only part of the way to the ocean as subyearlings, spend their first winter in the river or mainstem reservoirs, and continue their seaward migration as yearlings the following spring [25-27]. Reservoir-type fall Chinook salmon would have gone undetected because they likely resumed emigrating following the conclusion of PIT and acoustic tag monitoring and would therefore have been treated as mortalities in the Cormack-Jolly-Seber (CJS) model. It may be reasonable to assume that smaller fall Chinook salmon were more likely to be reservoir-type fish because anadromous fish may not smolt until reaching a threshold size [28], and because the rate of seaward movement among subyearling Chinook salmon increases with increasing fork length $[29,30]$. Therefore, we speculate that reservoir-type fall Chinook salmon may have biased the survival estimates of small (or any size) subyearling Chinook salmon. It is important to note that subyearling Chinook salmon were examined during only 1 year (as opposed to 3 years for yearling fish), warranting caution in the interpretation of these results until further replication and additional research can be conducted.

We also suggest caution when extrapolating these results to other systems, particularly to systems in which a greater proportion of individuals pass through turbines at dams. While a small fraction of tagged juvenile salmonids passed through turbines at the lower Snake and Columbia River Dams [31], a greater proportion of fish pass through turbines at other locations. Recent research has indicated that the survival of juvenile Chinook salmon (fork length range: $78 \mathrm{~mm}$ to $226 \mathrm{~mm}$ ) exposed to rapid pressure changes associated with turbine passage was negatively related to tag burden (range: $0.1 \%$ to $6.6 \%$ ) [31]. Fish with greater tag burdens were more likely to be injured or die when exposed to simulated turbine passage as compared to untagged fish or those with lower tag burdens. Therefore, a length-specific tag effect may manifest during research studies in systems where fish pass through turbines, because smaller acoustic-tagged fish with greater tag burdens may experience decreased survival as a result of pressure changes.

Laboratory-based tag effects studies have generally supported the contention that no length-specific tag effect should be expected for yearling Chinook salmon under the conditions used in this study. However, direct comparisons are difficult because most studies have evaluated size based on tag burden rather than length, and response variables (for example, survival, growth, predation, swimming performance, and stress levels) among studies are disparate. For example, Brown et al. [11] found that the growth of juvenile Chinook salmon was negatively influenced by implantation with an acoustic transmitter and PIT tag when the tag burden was greater than $8.2 \%$, and survival was negatively influenced when the tag burden was greater than $6.7 \%$. The swimming performance and predation susceptibility of acoustic-tagged juvenile Chinook salmon were not influenced by tag burdens up to $6.7 \%$ [6]. Another study found no correlation between fish size and cortisol level $24 \mathrm{~h}$ or $7 \mathrm{~d}$ after implantation of radio tags in juvenile Chinook salmon (length range: $140 \mathrm{~mm}$ to $260 \mathrm{~mm}$; tag burden range: $1.3 \%$ to $3.5 \%$ ) [5]. Among other species, it has been recommended that only steelhead O. mykiss parr greater than $74 \mathrm{~mm}$ should be implanted with PIT tags [32], and Zale et al. [22] did not find a negative influence on mean growth rate or swimming performance of cutthroat trout with tag burdens varying between $0.8 \%$ and $5.3 \%$. Thus, our study corroborates the literature from laboratory research in that relative to control fish, the size-specific survival of yearling Chinook salmon with tag burdens up to 5.7 (that is the largest median tag burden per size class encountered in this study) was not affected by the implantation or presence of an acoustic transmitter.

It is interesting to note that no length-specific tag effect was detected among subyearling Chinook salmon as tag burdens ranged from $2.5 \%$ to $15.1 \%$ and laboratory research has revealed reduced survival when the tag burden was greater than $6.7 \%$ [11]. The median tag burden experienced by each length-class of subyearling AT fish in the present study was $10.6 \%, 8.3 \%, 6.1 \%, 4.7 \%$, and $3.6 \%$, respectively, from the smallest length-class to the largest. Survival probabilities of the smallest length-class (that is, $80-89 \mathrm{~mm}$ ) of PIT and AT fish were similar and markedly lower than the survival probabilities of all other length bins. Thus, it may be surprising that no length-specific tag effect was detected within the second smallest length-class among which AT fish had a relatively high tag burden (a mean of $8.3 \%$ ). However, the fact that survival was very low for the smallest size category (with mean AT tag burdens of 10.6\%) for both tag types may have influenced the ability of the statistical models to identify size-related tag effects.

Consistent with previous findings [23,29,33-35], length was positively correlated with survival for nearly all year and reach combinations examined for both PIT and AT fish. One field study failed to detect a relationship between length and survival among acoustic-tagged 
Chinook salmon smolts emigrating through the Fraser River Basin [36]. However, this study utilized only larger Chinook salmon (that is, $>130 \mathrm{~mm}$ ) and evaluated the length-survival relationship by comparing the lengthfrequency distribution of all released fish to the distribution of fish known to survive to the mouth of the Fraser River. It is likely that the truncated length distribution, relatively small sample size $(n=348)$, and analytical methods used by Welch et al. [36] yielded a less sensitive analysis than that used in the present study.

Two primary hypotheses have been suggested regarding the cause of positive length-survival relationships among tagged fish: (1) chronic size-dependent mortality related to tagging and (2) size-dependent mortality unrelated to tagging [37]. Given the relatively unobtrusive nature of injecting PIT tags and the lack of a lengthspecific tag effect, we hypothesize that the positive relationship between fish length and survival was generally caused by trends in natural mortality (particularly among yearling Chinook salmon). This hypothesis may be important because some studies implant transmitters in only the larger individuals of a population to keep tag burdens below a certain limit (for example, $[36,38,39]$ ). While there is merit to this reasoning, a study may be equally biased by tagging only the larger individuals from a population because they may have greater natural survival rates than smaller individuals within the same population.

It also appears that length may also have an effect on PIT detection probability, as smaller fish were more likely to be detected. It is possible that smaller fish are more effectively diverted into the bypass, which could be attributed to behavioral (that is position in the water column) differences with size. The use of acoustic tags may reduce this bias. However, although no length-specific tag effects were found in AT fish, survival was generally greater for PIT fish but confounding variables necessitate caution in the interpretation of these results. The survival analysis conducted here used detections from PIT antennas that are present in the juvenile bypass systems of dams and compared it to AT detections at receivers present upstream in the forebay of the dams or downstream in the tailrace of dams. Consequentially, PIT antennas and acoustic receiver arrays were in the same general area near a dam, but they were not in precisely the same location. McNary Dam had the most disparity between detection locations: the acoustic array was located $18 \mathrm{~km}$ downstream from the corresponding PIT antennas. Acoustic arrays were located in the forebay of Lower Monumental and Ice Harbor Dams and the tailrace of McNary and John Day Dams. Thus, differences in survival between tag types could have been influenced by mortality incurred in the dam or river between detection locations. Direct comparisons of PIT-tagged fish to
AT fish made by Hockersmith et al. [14] and WargoRub et al. $[15,16]$ provide more robust measures of overall tag effects (non-size dependent). In these reports, PIT tag detections in both PIT-tagged and AT-tagged fish were made in the same locations, at PIT arrays in juvenile bypass systems. While those three studies were specifically designed to examine differences in survival between PIT and AT fish (that is, tag effects), they were not designed to examine length-specific tag effects as examined in this research.

Despite these aforementioned confounding variables, the large differences in survival to locations such as John Day Dam suggest that a tag effect was present, as was also documented by Wargo-Rub et al. $[15,16]$. However, our results indicate that this effect was not likely due to transmitter size because PIT and AT fish showed very similar length-survival relationships. Differences in survival between tag types may have been related to several factors. As previously mentioned, dam passage may account for some of the differences in survival between PIT and AT fish. Acoustic-tagged fish may have been more sensitive to dam passage than PIT fish among individuals that passed through turbines [30]. Further, acoustic-tagged fish were subjected to many potential stressors that PIT fish did not experience. Holding duration and conditions, handling, anesthesia, and the process of surgically implanting transmitters likely contributed to the greater tag effect observed among AT fish $[40,41]$. For example, AT fish were handled more than PIT fish and were anesthetized twice whereas, PIT fish were anesthetized only once.

Decreasing the size of incisions, reducing the amount of suture material used to close incisions, and reducing incision openness and ulceration, as well as better apposition of incisions, may reduce mortality, ultimately decreasing the tagging effect. Recent laboratory-based research has indicated that reducing the knot size and making surgical incisions on the linea alba can reduce the extent of tissue damage associated with surgical implantation of transmitters $[42,43]$. The laboratory-based research cited above has resulted in a surgical technique with a much smaller footprint, which is currently being used in research on seaward-migrating salmonids in the Columbia Basin, than that used in research conducted 4 to 6 years ago [14-16].

\section{Conclusions}

We suggest that no minimum size limit is required for implanting yearling or subyearling Chinook salmon with acoustic transmitters under the conditions used in this study. However, we recommend careful consideration prior to tagging subyearling Chinook salmon less than $90 \mathrm{~mm}$ due to the markedly low survival rates observed among both PIT and AT fish of this size. Although 
differences in survival between PIT and AT fish were observed, results suggest this tag effect in AT fish is due to the process of surgical implantation rather than the presence of the transmitter. Contemporary and future decreases in tag size and improvements in surgical technique may reduce or eliminate this disparity.

We assumed that the survival of PIT-tagged fish represented the survival of untagged fish. However, one study found that the smolt-to-adult survival of PIT-tagged Chinook salmon averaged $10 \%$ less than that of non-PIT -tagged fish [13]. Thus, it is likely that our assumption was violated due to the effect of the PIT tag on survival. Improvement of the PIT tagging process and procedures may lead to increased survival among these fish. Additional research is needed to examine the nature of any tag effects associated with PIT tagging before PIT-tagged fish can be effectively used as controls for such telemetry survival studies. Hopefully a continued push towards better fish handling and surgical techniques will greatly reduce tagging effects for all tag types. Further, this research demonstrates the need for careful consideration of experimental design when using either PIT tags or acoustic transmitters to evaluate the survival of juvenile Chinook salmon due to both length-specific detection and length-specific survival probabilities. This research highlights the need to reduce the effects of handling, holding, and tagging experienced by AT fish (and potentially PIT fish). Such improvements may increase the efficacy of acoustic telemetry research using juvenile salmonids smaller than those used in this study.

\section{Methods}

Seaward-migrating yearling Chinook salmon were collected at Lower Granite Dam in 2006, 2007, and 2008. During each year, one group was tagged with PIT tags (referred to as PIT fish) and another group was tagged with both PIT tags and Juvenile Salmon Acoustic Telemetry System (JSATS) [44] acoustic transmitters (referred to as AT fish). Fish were subsequently released, and length-specific survival to multiple downstream locations was compared between PIT and AT fish. The aforementioned methods were also conducted using subyearling Chinook salmon in 2007. Acoustic transmitters decreased in size each year due to technological advances. The tag weight was $0.66 \mathrm{~g}$ in $2006,0.64 \mathrm{~g}$ or 0.60 $\mathrm{g}$ in 2007 and $0.42 \mathrm{~g}$ in 2008. The PIT tag weight remained the same for all 3 years at $0.1 \mathrm{~g}$. The tag burden (Figure 2 and Table 2) was calculated using the total weight of both tags.

\section{Fish collection, tagging, and release}

Chinook salmon were sampled from the smolt collection facility at Lower Granite Dam and diverted into a concrete raceway for holding. Within $12 \mathrm{~h}$ to $18 \mathrm{~h}$ of collection, fish were sorted under light anesthesia using clove oil $(10 \mathrm{mg} / \mathrm{L})$ as an induction agent followed by tricaine methanesulfonate (MS-222) $[45,46]$. Hatcheryorigin Chinook salmon that had not been previously PIT tagged, had no visual signs of disease or injury, and met annual length criteria (see Table 2 for annual length ranges examined) were selected for tagging. Immediately after they were sorted, Chinook salmon designated as PIT fish were measured for fork length $(\mathrm{mm})$, a PIT tag was injected into the body cavity (see Prentice et al. $[47,48]$ for methods), and they were transferred to a 18,900-L tank supplied with flow-through river water. Fish were held for $12 \mathrm{~h}$ to $24 \mathrm{~h}$ until release. For the water temperature during holding, refer to Hockersmith et al. [14] and Wargo-Rub et al. [15,16].

The Chinook salmon designated as AT fish were sorted and then transferred to a 75-L holding tank where they were allowed to recover from anesthesia for $18 \mathrm{~h}$ to $24 \mathrm{~h}$ prior to tagging. Prior to surgery, AT fish were placed in an anesthetic bath containing MS-222 concentrations ranging from $50 \mathrm{mg} / \mathrm{L}$ to $80 \mathrm{mg} / \mathrm{L}$ until reaching stage 4 anesthesia [49]. Each AT fish was surgically implanted with both a JSATS acoustic transmitter and a PIT tag using methods modified from Deters et al. [50]. Briefly, fish were measured for fork length $(\mathrm{mm})$ and weight $(\mathrm{g})$ and placed ventral side up on a surgery table. A 6- to 8$\mathrm{mm}$ incision was made 2 to $5 \mathrm{~mm}$ from, and parallel to, the linea alba, just anterior to the pelvic girdle. The PIT and acoustic tags were inserted into the peritoneal cavity, and the incision was closed using two interrupted sutures (Vicryl in 2006 or Monocryl in 2007 and 2008, 5-0 absorbable monofilament). Fish tagged with acoustic transmitters were transferred to the same 18,900 - $\mathrm{L}$ tank as the PIT fish where they were held overnight until release. Both groups (AT and PIT) were simultaneously released into the tailrace of Lower Granite Dam through a $10-\mathrm{cm}$ diameter flexible hose connected to their common holding tank.

Tagging was conducted over multiple days during each year, and each tagging day was followed by a subsequent release day. Yearling Chinook salmon were released across two dates (that is, in two release groups) in 2006: 6 May and 13 May. Yearling Chinook salmon consisted of ten release groups in both 2007 (25 April to 15 May) and 2008 (24 April to 17 May). Subyearling Chinook salmon consisted of 27 release groups (5 June to 14 July) in 2007. During the three years of yearling Chinook salmon evaluation, 121,870 PIT and 8,740 AT fish were tagged, released, and monitored (Table 2). During 2007, 35,793 PIT and 9,760 AT subyearling Chinook salmon were tagged, released, and monitored (Table 2). A greater number of PIT fish than AT fish were required to achieve the same precision in survival estimates due to a 
known disparity in detection probability between tag types (see Results).

\section{Post-release monitoring}

Passive integrated transponder fish were monitored using PIT tag detectors at dams. Automated PIT tag interrogation systems (see Axel et al. [51] for specifications) are installed at Lower Monumental, Ice Harbor, McNary, and John Day Dams (Figure 1). As smolts approached these dams, many were diverted away from the turbines and through juvenile bypass systems consisting of a series of flumes and pipes that route fish around the dam and back to the river. The juvenile bypass systems at these dams are equipped with arrays of PIT tag detection antennae that automatically detected and recorded the tag code and time of passage of each PIT-tagged individual that passed through the system. Only fish passing through the juvenile bypass systems were detected. Fish detection probability is dependent on for example, the number of PIT-tagged fish passing the detector at one time (that is two PIT tags would cancel each other out).

Autonomous receivers (Model N201, Sonic Concepts Inc., Bothell, WA) were used to detect the acoustic signals of passing AT fish, each with an individual code [44]. Acoustic arrays were located either in the forebay or tailrace of each of the aforementioned dams (Table 3), depending on design of survival studies or other studies during each year. Receivers comprised electronics, onboard power, data storage, and a hydrophone housed in a polyvinyl chloride tube, and were anchored to the river bottom using a 35-kg anchor and shock-corded mooring to an acoustic release [52]. At each monitoring location, receivers were deployed as arrays (that is, multiple units across and perpendicular to the river channel) with an overlap in detection ranges among receivers. Unlike the PIT tag arrays, all routes of passage are monitored and detection efficiencies approach $100 \%$ at many locations. Receivers were recovered and serviced biweekly throughout the study period each year.

\begin{tabular}{|c|c|c|c|}
\hline \multirow{2}{*}{ Detection point } & \multicolumn{2}{|c|}{ Reach length (rkm) } & \multirow{2}{*}{ Location of AT arra } \\
\hline & PIT fish & AT fish & \\
\hline Lower Monumental Dam & 106 & 106 & Forebay \\
\hline Ice Harbor Dam & 157 & 157 & Forebay \\
\hline McNary Dam & 225 & 243 & Tailrace \\
\hline John Day Dam & 348 & 354 & Tailrace \\
\hline
\end{tabular}

AT acoustic transmitter, PIT passive integrated transponder.

Survival was estimated to four downstream dams. All PIT detections occurred at the dam face but acoustic (AT) detections occurred either in the forebay or tailrace, as specified.

\section{Statistical analyses}

This large dataset spans several years and includes variable detection efficiencies and uneven sample sizes within length categories. Several different analyses were conducted and summarized as justification for the final methodology used. The presented results are the product of a statistical method that followed all assumptions and for which, given the complex nature of this dataset, visualization and interpretation were straightforward.

Although tag burden is a commonly used guide for making inferences regarding tag size appropriateness $[8,53,54]$, length was used as a surrogate for tag burden in this study because measurements of weight were not recorded for PIT fish. This is standard practice when using PIT-tagged fish as controls to minimize handling. Analyses were conducted independently for each combination of stock (yearling and subyearling), year (2006, 2007, and 2008), and tag type (PIT and AT); the combinations are referred to hereafter as cohorts. The several downstream detection sites (that is Lower Monumental, Ice Harbor, McNary and John Day Dams) were not included in a single model because the same fish arrive at each dam. Thus including all data in one model would mean analyzing the same fish multiple times. Furthermore, fish swim different distances and encounter different conditions at each dam.

Within each cohort, individuals from all release groups were pooled and then partitioned into $10-\mathrm{mm}$ bins (length-classes) based on fork length. Only lengthclasses containing 100 individuals or more were used in further analyses. Thus, although data originally collected and reported by Hockersmith et al. [14] and Wargo-Rub et al. $[15,16]$ were used for this analysis, only a subset of those data were used. Probabilities of detection and survival (that is, the probability of survival, migration, and tag function and retention) were analyzed independently within each length-class using the single releaserecapture model (hereafter referred to as the CJS model) developed by Cormack [55], Jolly [56], and Seber [57]. The CJS model was used to calculate detection and survival probabilities and associated variability of Chinook salmon released at Lower Granite Dam to downstream detection sites (Table 2). For each reach of interest (for example, Lower Granite Dam to Lower Monumental Dam, Lower Granite Dam to John Day Dam), detection and survival probabilities were calculated for each length-class within each cohort.

CJS analyses were initially performed with length as a covariate but it was found that detection estimates for different fish lengths were overwhelmingly influencing survival estimates. Smaller fish had high detection probabilities, leading to higher survival estimates compared to larger fish with low detection probabilities. The CJS modeling program (SURPH.3, University of Washington, 
Seattle) does not calculate detection probability independently for differing sizes of fish. Rather, SURPH.3 applies the overall detection probability of all fish in the cohort to each survival estimate. Indeed, length has been shown to be negatively correlated with the detection probability of PIT-tagged Chinook salmon at Snake and Columbia River dams [35]. However, to confirm results were biased by variable detection probabilities, smaller and larger fish were analyzed separately without a covariate and survival rates were almost entirely dependent on detection rates. Thus, treating length as a covariate in the CJS model could overestimate the survival of length-classes for which detection probability was greater than the mean detection probability of the cohort (that is, small fish; see Results) and underestimate survival of length-classes for which detection probability was less than that of the entire cohort (that is, large fish; see Results). After repeatedly seeing this pattern, the length covariate was removed and CJS estimates were calculated for each length bin separately.

Weighted linear regression was used to assess the strength of correlation (that is, $r^{2}$ ) between length and survival for each cohort-reach combination. The weighting term used is the inverse of the coefficient of variation, squared. Weight was therefore expressed as:

$$
w t=\frac{1}{C V^{2}}=\frac{1}{\left(\frac{S E(\hat{S})}{\hat{S}}\right)^{2}}=\frac{1}{\left(\frac{S E(\hat{S})}{\hat{S}}\right)^{2}}=\frac{\hat{S}^{2}}{S E(\hat{S})^{2}}
$$

where $\hat{S}=$ survival probability. Weighted two-way analysis of variance (ANOVA) was used to compare the survival probabilities of PIT and AT fish. Length-class, tag type, and the interaction term were included as covariates in the models. The interaction term was used to indicate whether survival of PIT fish was influenced by length in a manner similar to that of AT fish (that is, did length affect the survival of PIT fish in the same manner in which it influenced the survival of AT fish?). $\alpha$ was 0.05 for all analyses.

Alternatively, in an attempt to simplify the presented analyses, further analyses were conducted by comparing the ratio of survival rates between AT and PIT fish with year and bin length as covariates. Although it was thought this method may provide a more allencompassing analysis, visually interpreting the data was challenging. The amplitude of the survival values were lost, comparison of mean survival estimates was based on a test of an intercept of value 1 , and a test of equal trends was based on a test of a slope equal to 0 . Visually, with one regression line (that is, the change in the ratio of survival with length), one cannot identify where discrepancies in survival exist between tag types. Conversely, as presented, analyses and plots allow a direct conveyance of survival probabilities among lengths, tag types, and any interaction between the two. Furthermore, analyses presented in the results are preferred, since original observations are modeled rather than constructs of the data [58].

PIT detections were used for PIT fish and AT detections were used for AT fish. Although AT fish also received PIT tags, the limited sample sizes of AT fish and poor detection efficiency of PIT arrays (see Results) prohibited the use of PIT detections for an analysis where data were binned by length. Therefore, detection points at each dam were sometimes at different locations between groups (see Table 3). However, these differences in detection location do not influence our interpretation of the data given that we were primarily interested in differences in the relationship between length and survival with tag type, not the main effects of survival.

\section{Abbreviations}

AT: Acoustic transmitter; CJS model: Cormack-Jolly-Seber model; JSATS: Juvenile salmon acoustic telemetry system; NA: Not applicable; RT: Radio transmitter; PIT: Passive integrated transponder.

\section{Competing interests}

The authors declare that they have no competing interests.

\section{Authors' contributions}

RSB and KAD designed, prepared, and executed the experiments of this study. JRS and AGS analyzed the data. RSB, EWO, and KVC drafted the manuscript and completed revisions. MBE conceived the study and helped with study design and funding. All authors read and approved the final manuscript.

\section{Authors' information}

RSB, EWO, and KAD are scientists at the Pacific Northwest National Laboratory. KVC is a research associate at the Pacific Northwest National Laboratory. JRS and AGS are statisticians in the School of Aquatic and Fishery Sciences, University of Washington. MBE is a fish biologist for the US Army Corps of Engineers, Portland District.

\section{Acknowledgments}

Funding for this research was provided by the US Army Corps of Engineers, Portland District. Research of this magnitude would not have been possible without the contributions of many individuals and organizations. Thank you to Mike Halter, Ben Hausmann, Greg Moody, John Bailey, and Dave Hurson of the US Army Corps of Engineers. We thank Peter Kuechle and Sheldon Struthers of Advanced Telemetry Systems for sharing their expertise. Tag activation, delivery, and help in the field were provided by Brenda James, Paul James, Keith Pitts, Kara Prather, and Andrew Puls of Cascade Aquatics. The National Oceanic and Atmospheric Administration Fisheries was instrumental in the planning and implementation of this study, particularly the Pasco shop and Lower Granite Dam PIT tagging crew. Specifically, we thank Doug Marsh for his invaluable assistance and guidance, as well as Shane Collier, Scott Davidson, Jason Everett, John Ferguson, Kinsey Frick, Patricia Harshman, Eric Hockersmith, Gene Mathews, Lynn McComas, Ken Mclntyre, Mark Myers, Neil Paasch, Mark Peterson, A. Michelle Wargo-Rub, Tom Ruhle, and Ben Sandford. The Pacific States Marine Fisheries

Commission, including Dean Ballinger, Larry Basham, Chris Eaton, Ethan Ellsworth, Keith Morris, Robert Horal, and Cheryl Engle, provided help in the field and laboratory. Thank you to Fred Mensik, Shawn Rapp, and Doug Ross of the Washington Department of Fish and Wildlife for their advice and assistance with the monitoring program. We thank Rebecca Buchanan of the University of Washington for her statistical consultation. Pacific Northwest National Laboratory (PNNL) employees working on this research included Carmina Arimescu, Brian Bellgraph, Matt Bleich, Jim Boyd, Kathleen Carter, Andrea Currie, Corey Duberstein, James Hughes, Jill Janak, Jennifer Monroe, 
Katie Klett, Katie Ovink, Jennifer Panther, Nathan Phillips, John Stephenson, Scott Titzler, Abby Welch, Shon Zimmerman, Craig Allwardt, Marie Theriault, James Boyd, Jessica Carter, Dennis Dauble, Gayle Dirkes, David Geist, Christa Woodley, Kenneth Ham, Ryan Harnish, Julie Hughes, Kathy Lavender, Geoffrey McMichael, R. Eric Robinson, Donna Trott, and lan Welch. Animals were handled in accordance with federal guidelines for the care and use of laboratory animals, and protocols were approved by the Institutional Anima Care and Use Committee, Battelle-Pacific Northwest Division. A multiprogram national laboratory, PNNL is operated by Battelle for the US Department of Energy under Contract DE-AC05-76RL01830.

\section{Author details}

'Pacific Northwest National Laboratory, Ecology Group, Post Office Box 999, Richland, WA 99352, USA. ${ }^{2}$ School of Aquatic and Fishery Sciences, University of Washington, 1325 Fourth Avenue, Suite 1820, Seattle, WA 98112, USA. ${ }^{3}$ US Army Corps of Engineers, Portland District, Post Office Box 2946, Portland, OR 97208-2946, USA.

Received: 29 March 2013 Accepted: 9 April 2013

Published: 12 June 2013

\section{References}

1. Jepsen N, Aarestrup K, Okland F, Rasmussen G: Survival of radio-tagged Atlantic salmon (Salmo salar L.) and brown trout (Salmo trutta L.) smolts passing a reservoir during seaward migration. Hydrobiologia 1998, 371(372):347-353.

2. Lucas MC, Baras E: Methods for studying spatial behavior of freshwater fishes in the natural environment. Fish Fish 2000, 1:283-316.

3. Peven C, Giorgi A, Skalski JR, Langeslay M, Grassell A, Smith S, Counihan T, Perry R, Bickford S: Guidelines and Suggested Protocols for Conducting, Analyzing, and Reporting Juvenile Salmonid Survival Studies in the Columbia River Basin. Columbia Basin Research, Seattle, WA: University of Washington School of Aquatic \& Fishery Sciences; 2005.

4. Peake S, McKinley RS, Scruton DA, Moccia R: Influence of transmitter attachment procedures on swimming performance of wild and hatchery-reared Atlantic salmon smolts. Trans Am Fish Soc 1997, 126:707-714.

5. Jepsen N, Davis LE, Schreck CB, Siddens B: The physiological response of Chinook salmon smolts to two methods of radio-tagging. Trans Am Fish Soc 2001, 130:495-500.

6. Anglea SM, Geist DR, Brown RS, Deters KA, McDonald RD: Effects of acoustic transmitters on swimming performance and predator avoidance of juvenile Chinook salmon. North American J Fisheries Manage 2004, 24:162-170.

7. Lacroix GL, Knox D, McCurdy P: Effects of implanted dummy acoustic transmitters on juvenile Atlantic salmon. Trans Am Fish Soc 2004, 133:211-220.

8. Brown RS, Geist DR, Deters KA, Grassell A: Effects of surgically implanted acoustic transmitters $>2 \%$ of body mass on the swimming performance, survival and growth of juvenile sockeye and Chinook salmon. J Fish Biol 2006, 69:1626-1638.

9. Welch DW, Batten SD, Ward BR: Growth, survival, and tag retention of steelhead trout (O. mykiss) surgically implanted with dummy acoustic tags. Hydrobiologia 2007, 582:289-299.

10. Hall JE, Chamberlin J, Kagley AN, Greene C, Fresh KL: Effects of gastric and surgical insertions of dummy ultrasonic transmitters on juvenile Chinook salmon in seawater. Trans Am Fish Soc 2009, 138:52-57.

11. Brown RS, Harnish RA, Carter KM, Boyd JW, Deters KA: An evaluation of the maximum tag burden for implantation of acoustic transmitters in juvenile Chinook salmon. North American J Fisheries Manage 2010, 30:499-505.

12. Hockersmith EE, Muir WD, Smith SG, Sandford BP, Perry RW, Adams NS, Rondorf DW: Comparison of migration rate and survival between radio-tagged and PIT-tagged migrant yearling Chinook salmon in the Snake and Columbia rivers. North American J Fisheries Manage 2003, 23:404-413.

13. Knudsen CM, Johnston MV, Schroder SL, Bosch WJ, Fast DE, Strom CR Effects of passive integrated transponder tags on smolt-to-adult recruit survival, growth, and behavior of hatchery spring Chinook salmon. North American J Fisheries Manage 2009, 29:658-669.

14. Hockersmith EE, Brown RS, Liedtke TL: Comparative Performance of Acoustic Tagged and Passive Integrated Transponder-Tagged Juvenile Salmonids, Report to the US Army Corps of Engineers, Portland District. Seattle, WA: Northwest Fisheries Science Center; 2008.
15. Wargo-Rub AM, Brown RS, Sanford BP, Deters KA, Gilbreath LG, Myers MS, Peterson ME, Harnish RA, Oldenburg EW, Carter JA, Welch IW, McMichael GA, Boyd JA, Hockersmith EE, Matthews GM: Comparative Performance of Acoustic Tagged and Passive Integrate Transponder-Tagged Juvenile Salmonids in the Columbia and Snake Rivers, 2007, Report to the US Army Corps of Engineers, Portland District. Seattle, WA: Northwest Fisheries Science Center; 2009.

16. Wargo Rub AM, Sanford BP, Gilbreath LG, Myers MS, Peterson ME, Charlton LL, Smith SG, Matthews GM: Comparative Performance of Acoustic Tagged and Passive Integrate Transponder-Tagged Juvenile Chinook salmon in the Columbia and Snake Rivers, 2008, Report to the US Army Corps of Engineers, Portland District. Seattle, WA: Northwest Fisheries Science Center; 2011.

17. Skalski JR, Townsend RL, Steig TW, Horchik JW, Tritt GW, Grassell A: Estimation of Rock Island Project Passage Survival of Yearling Chinook Salmon Smolts in 2003 Using Acoustic and PIT Tag Release-Recapture Methods. Wenatchee, WA: Report by Columbia Basin Research and Hydroacoustic Technology, Incorporated; 2003

18. Skalski JR, Townsend RL, Steig TW, Nealson PA, Kumagai KK, Grassell A: Estimation of Survival of Yearling and Subyearling Chinook, and Sockeye Salmon Smolts, and Steelhead at Rocky Reach and Rock Island Projects in 2004 Using Acoustic and PIT Tag Release-Recapture Methods. Wenatchee, WA: Report by Columbia Basin Research and Hydroacoustic Technology, Incorporated; 2005.

19. Skalski JR, Townsend RL, Steig TW, Nealson PA, Grassell A: Survival of yearling Chinook, Sockeye Salmon, and Steelhead Smolts Through Rocky Reach and Rock Island Projects in 2005. Wenatchee, WA: Report by Columbia Basin Research and Hydroacoustic Technology, Incorporated; 2006.

20. Faulkner JR, Smith SG, Muir WD, Marsh DM, Williams JG: Survival Estimates for the Passage of Spring-Migrating Juvenile Salmonids Through Snake and Columbia River Dams and Reservoirs. Portland, OR: Report by National Marine Fisheries Service, Fish Ecology Division; 2009.

21. Adams NS, Rondorf DW, Evans SD, Kelly JE, Perry RW: Effects of surgically and gastrically implanted radio transmitters on swimming performance and predator avoidance of juvenile Chinook salmon (Oncorhynchus tshawytscha). Canadian J Fisheries Aquatic Sci 1998, 55:781-787.

22. Zale AV, Brooke C, Fraser WC: Effects of surgically implanted transmitter weights on growth and swimming stamina of small adult westslope cutthroat trout. Trans Am Fish Soc 2005, 134:653-660.

23. Connor WP, Smith SG, Andersen T, Bradbury SM, Burum DC, Hockersmith EE, Schuck ML, Mendel GW, Bugert RM: Post-release performance of hatchery yearling and subyearling fall Chinook salmon released into the Snake River. North American J Fisheries Manage 2004, 24:545-560

24. Connor WP, Tiffan KF: Evidence for parr growth as a factor affecting parr-to-smolt survival. Trans Am Fish Soc 2012, 141:1207-1218.

25. Connor WP, Burge HL, Waitt R: Juvenile life history of wild fall Chinook salmon in the Snake and Clearwater rivers. North American J Fisheries Manage 2002, 22:703-712

26. Connor WP, Sneva JG, Tiffan KF, Steinhorst RK, Ross D: Two alternative juvenile life history types for fall Chinook salmon in the Snake River Basin. Trans Am Fish Soc 2005, 134:291-304.

27. Buchanan RA, Skalski JR, McMichael GA: Differentiating mortality from delayed migration in subyearling fall Chinook salmon (Oncorhynchus tshawytscha). Canadian J Fisheries Aquatic Sci 2009, 66:2243-2255.

28. Wedemeyer GA, Saunders RL, Clarke WC: Environmental factors affecting smoltification and early marine survival of anadromous salmonids. US National Marine Fisheries Serv Marine Fisheries Rev 1980, 42:1-14.

29. Connor WP, Steinhorst RK, Burge HL: Forecasting survival and passage of migratory juvenile salmonids. North American J Fisheries Manage 2000, 20:651-660

30. Connor WP, Steinhorst RK, Burge HL: Migrational behavior and seaward movement of wild subyearling fall Chinook salmon in the Snake River. North American J Fisheries Manage 2003, 23:414-430.

31. Carlson TJ, Brown RS, Stephenson JR, Pflugrath BD, Colotelo AH, Gingerich AJ, Benjamin PL, Langeslay MJ, Ahmann ML, Johnson RL, Skalski JR, Seaburg $A G$, Townsend RL: The influence of tag presence on the mortality of juvenile Chinook salmon exposed to simulated hydroturbine passage: implications for survival estimates and management of hydroelectric facilities. North American J Fisheries Manage 2012, 32:249-261.

32. Tatara CP: Size at implantation affects growth of juvenile steelhead implanted with 12-mm passive integrated transponders. North American J Fisheries Manage 2009, 29:417-422.

33. Zabel RW, Achord S: Relating size of juveniles to survival within and among populations of Chinook salmon. Ecology 2004, 85:795-806. 
34. Monzyk FR, Jonasson BC, Hoffnagle TL, Keniry PJ, Carmichael RW, Cleary PJ: Migration characteristics of hatchery and natural spring Chinook salmon smolts from the Grande Ronde River basin, Oregon, to Lower Granite Dam on the Snake River. Trans Am Fish Soc 2009, 138:1093-1108.

35. Zabel RW, Wagner T, Congleton JL, Smith SG, Williams JG: Survival and selection of migrating salmon from capture-recapture models with individual traits. Ecol Appl 2005, 15:1427-1439.

36. Welch DW, Melnychuk MC, Payne JC, Rechisky EL, Porter AD, Jackson GD, Ward BR, Vincent SP, Wood CC, Semmens J: In situ measurement of coastal ocean movements and survival of juvenile Pacific salmon. Proc Natl Acad Sci USA 2011, 108:8708-8713.

37. Brakensiek KE, Hankin DG: Estimating overwinter survival of juvenile coho salmon in a northern California stream: accounting for effects of passive integrated transponder tagging mortality and size-dependent survival. Trans Am Fish Soc 2007, 136:1423-1437.

38. Rechisky EL, Welch DW, Porter AD, Jacobs MC, Ladouceur A: Experimental measurement of hydrosystem-induced delayed mortality in juvenile Snake River spring Chinook salmon (Oncorhynchus tshawytscha) using a large-scale acoustic array. Canadian J Fisheries Aquatic Sci 2009, 66:1010-1024

39. Dempson JB, Robertson MJ, Pennell CJ, Furey G, Bloom M, Shears M, Ollerhead LMN, Clarke KD, Hinks R, Robertson GJ: Residency time, migration route and survival of Atlantic salmon Salmo salar smolts in a Canadian fjord. J Fish Biol 2011, 78:1976-1992.

40. Oldenburg EW, Colotelo AH, Brown RS, Eppard MB: Holding of juvenile salmonids for surgical implantation of electronic tags: a review and recommendations. Rev Fish Biol Fisheries 2011, 21:35-42.

41. Wagner GN, Cooke SJ, Brown RS, Deters KA: Surgical implantation techniques for electronic tags in fish. Rev Fish Biol Fisheries 2011, 21:71-81.

42. Panther JL, Brown RS, Gaulke GL, Deters KA, Woodley CM, Eppard MB: Influence of incision location on transmitter loss, healing, incision length, and suture retention of juvenile Chinook salmon. Trans Am Fish Soc 2011, 140:1492-1503

43. Deters KA, Brown RS, Boyd JW, Eppard MB, Seaburg AG: Optimal suturing technique and number of sutures for surgical implantation of acoustic transmitters in juvenile salmonids. Trans Am Fish Soc 2012, 141:1-10.

44. McMichael GA, Eppard MB, Carlson TJ, Carter JA, Ebberts BD, Brown RS, Weiland M, Ploskey GR, Harnish RA, Deng ZD: The juvenile salmon acoustic telemetry system: a new tool. Fisheries 2010, 35:9-22.

45. Marsh DM, Harmon JR, Mclntyre KW, Thomas KL, Paasch NN, Sandford BP Kamikawa DJ, Matthews GM: Research Related to Transportation of Juvenile Salmonids on the Columbia and Snake Rivers, 1995. Walla Walla, WA: Report of the National Marine Fisheries Service; 1996.

46. Marsh DM, Harmon JR, Paasch NN, Thomas KL, Mclntyre KW, Sandford BP, Matthews GM: Research Related to Transportation of Juvenile Salmonids on the Columbia and Snake Rivers, 2000. Walla Walla, WA: Report of the National Marine Fisheries Service; 2001.

47. Prentice EF, Flagg TA, McCutcheon SC: Feasibility of using implantable passive integrated transponder (PIT) tags in salmonids. Am Fish Soc Symp 1990, 7:317-322

48. Prentice EF, Flagg TA, McCutcheon CS, Brastow DF: PIT tag monitoring systems for hydroelectric dams and fish hatcheries. Am Fish Soc Symp 1990, 7:323-334.

49. Summerfelt RC, Smith LS: Anesthesia, surgery, and related techniques. In Methods for Fish Biology. Edited by Schreck CB, Moyle PB. Bethesda, Maryland: American Fisheries Society; 1990:213-272.

50. Deters KA, Brown RS, Carter KM, Boyd JW, Eppard MB, Seaburg AG: Performance assessment of suture type, water temperature, and surgeon skill in juvenile Chinook salmon surgically implanted with acoustic transmitters. Trans Am Fish Soc 2010, 139:888-899.

51. Axel GA, Prentice EF, Sandford BP: PIT tag detection system for large-diameter juvenile fish bypass pipes at Columbia River Basin hydroelectric dams. North American J Fisheries Manage 2005, 25:646-651.

52. Titzler PS, McMichael GA, Carter JA: Autonomous acoustic receiver deployment and mooring techniques for use in large rivers and estuaries. North American J Fisheries Manage 2010, 30(4):853-859.

53. Winter J: Advances in underwater biotelemetry. In Fisheries Techniques. 2nd edition. Edited by Murphy BR, Willis DW. Bethesda, Maryland: American Fisheries Society; 1996:555-590.
54. Brown RS, Cooke SJ, Anderson WG, McKinley RS: Evidence to challenge the '2\% rule' for biotelemetry. North American J Fisheries Manage 1999, 19:867-71.

55. Cormack RM: Estimates of survival from the sighting of marked animals. Biometrika 1964, 51:429-438.

56. Jolly GM: Explicit estimates from capture-recapture data with both death and immigration-stochastic model. Biometrika 1965, 52:225-247.

57. Seber GAF: A note on the multiple recapture census. Biometrika 1965, 52:249-259.

58. McCullagh P, Nelder JA: Generalized Linear Models. 2nd edition. London: Chapman \& Hall; 1989.

doi:10.1186/2050-3385-1-8

Cite this article as: Brown et al:: Survival of seaward-migrating PIT and acoustic-tagged juvenile Chinook salmon in the Snake and Columbia Rivers: an evaluation of length-specific tagging effects. Animal Biotelemetry 2013 1:8

\section{Submit your next manuscript to BioMed Central and take full advantage of:}

- Convenient online submission

- Thorough peer review

- No space constraints or color figure charges

- Immediate publication on acceptance

- Inclusion in PubMed, CAS, Scopus and Google Scholar

- Research which is freely available for redistribution 